\title{
ALCOHOL CONSUMPTION AMONG UNIVERSITY STUDENTS IN SPAIN
}

\author{
D. QUEIPO, F.J. ALVAREZ and A. VELASCO
}

Departments of Legal Medicine, and Pharmacology and Therapeutics, Faculty of Medicine, University of Valladolid, (Spain)

(Received February 4th, 1986)

\section{SUMMARY}

Alcohol consumption in 1984 among 2921 students of nine Faculties in the University of Valladolid (Spain) is reported. Alcoholic drinks were frequently consumed, especially by males and during weekends. Per capita consumption was $9.85 \mathrm{l}$ of absolute alcohol/year for males and 4.971 for females. Beer, wine and gin were the favourite drinks. Alcohol consumption was similar in the different faculties and age groups but was to some extent related to age and place of residence in male students. Students' alcohol consumption was not as high as in the general Spanish population, and seems to have been stable during the last 10 years.

Key words: Alcohol consumption - University students - Characteristics Spain

\section{INTRODUCTION}

Spain is considered one of the principal producer and consumer countries of alcoholic drinks [1-3]. However, most of the available data have been obtained from production figures, those obtained from epidemiological studies being very limited. Alcohol consumption among University students has been investigated [4,5] in other Spanish regions, but not in the area of Old Castile and Leon. Accordingly, we examined alcohol consumption in nine Faculties in the University of Valladolid.

\section{MATERIALS AND METHODS}

The questionnaire consisted of two sections, one referring to affiliation: Faculty, academic year, age, place of residence during the course, the other 
section referring to alcohol consumption: kind and quantity of drink consumed both during the weekend and the rest of the week.

Questionnaires were distributed before or after lectures, being preceded by some explanations of the reasons for the survey, its anonymous character and instructions for completion (generally, within $15 \mathrm{~min}$ ) being collected later.

\section{Subjects}

Students (2921) of nine Faculties in the University of Valladolid properly completed the questionnaire. Distribution according to Faculty, academic year and sex is shown in Table I. The surveyed students comprised $25.8 \%$ of the total of students matriculated in the University of Valladolid in 1984.

\section{Data processing}

Testimonies have been codified in a VAX 11/780 computer with VMS operative system by the Data Processing Centre in the University of Valladolid, having been treated with a package of standard statistics programmes.

\section{Expression of results}

The quantities of alcohol consumed have been expressed as grams of absolute alcohol consumed per day in accordance with the equivalences shown in Table II. A $\chi^{2}$-test was performed for statistical significance.

\section{RESULTS}

Alcoholic drinks were consumed more frequently $(P<0.01)$ and to a higher extent $(P<0.01)$ by males than by females, both during the weekend and the rest of the week (Table III). Figure 1 shows that most consumed between 1 and $39 \mathrm{~g} /$ day both during the weekend and the rest of the week, and that $19.5 \%$ of males and $3.3 \%$ of females were heavier drinkers (over $80 \mathrm{~g} /$ day) during the weekend.

All the alcoholic drinks (Table IV) were consumed more frequently $(P<0.01)$ and to a higher extent $(P<0.01)$ during the weekend than during the rest of the week, especially drinks of high alcoholic content. Beer and wine were the favourite drinks; gin was the most consumed spirit.

Alcohol consumption (frequency, quantity and kind of drink) were similar throughout the different faculties (data not shown, $P>0.05$ ). Also, alcohol consumption was similar throughout the different academic years $(P>0.05$, Table V). However, a relationship was found $(P<0.05)$ between alcohol consumption and age (18-25 years) in male students, but not $(P>0.05)$ in female students (Fig. 2). Female students $(P>0.05)$ consume alcohol to similar extents independently of their place of residence during 


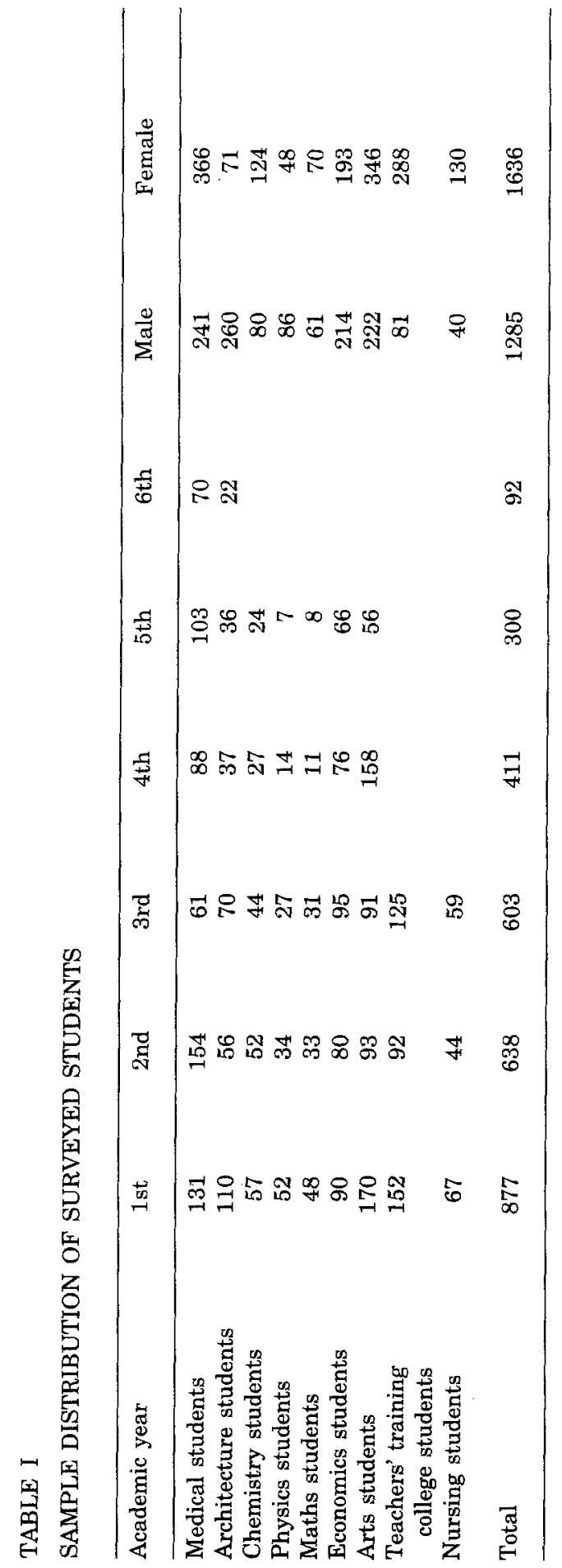


TABLE II

ALCOHOLIC DEGREE OF SPANISH DRINKS

\begin{tabular}{lcrc}
\hline Kind of drink & $\begin{array}{l}\text { Alcoholic } \\
\text { degree }\end{array}$ & $\begin{array}{c}\text { Vol. } \\
\text { (ml) }\end{array}$ & $\begin{array}{c}\text { g/of } \\
\text { alcohol }\end{array}$ \\
\hline Beer & 4.0 & 200 & 6.4 \\
Wine & 10.0 & 50 & 4.0 \\
Champagne & 13.0 & 100 & 10.4 \\
Sherry & 17.0 & 50 & 6.8 \\
Vermouth & 16.0 & 70 & 9.0 \\
Cognac (alone or mixed) & 40.0 & 50 & 16.0 \\
Anisette & 36.0 & 50 & 14.0 \\
Cognac and anisette & 38.0 & 50 & 15.0 \\
Punch & 28.0 & 50 & 11.2 \\
Gin (alone or mixed) & 40.0 & 50 & 16.0 \\
Rum (alone or mixed) & 42.0 & 50 & 16.8 \\
Vodka (alone or mixed) & 42.0 & 50 & 16.8 \\
Whiskey (alone or mixed) & 45.0 & 50 & 18.0 \\
Cointreau (alone or mixed) & 40.0 & 50 & 16.0 \\
Pacharan & 28.0 & 50 & 11.2
\end{tabular}

${ }^{\text {a }}$ State the volume of intake of every one of the different drinks. Beer and wine have different volumes. Beer 'corto': $100 \mathrm{ml}$; 'cana' and 'beer 1/5': $200 \mathrm{ml}$; 'beer 1/3': $330 \mathrm{ml}$. Wine 'chato': $50 \mathrm{ml}$; 'glass': $100 \mathrm{ml}$.

${ }^{b}$ Grams of pure alcohol in relation to the volume stated above.

TABLE III

CONSUMPTION OF ALCOHOL ACCORDING TO SEX BY UNIVERSITY STUDENTS

\begin{tabular}{|c|c|c|c|c|}
\hline \multirow{2}{*}{$\begin{array}{l}\text { Consumption } \\
\text { of alcohol }\end{array}$} & \multicolumn{2}{|l|}{ Male } & \multicolumn{2}{|l|}{ Female } \\
\hline & $\begin{array}{l}\% \\
\text { of students }\end{array}$ & $\mathrm{g} \pm$ S.E.M. $/$ day & $\begin{array}{l}\% \\
\text { of students }\end{array}$ & $\mathrm{g} \pm$ S.E.M. $/$ day \\
\hline Overall & 90.2 & $21.6 \pm 0.6$ & $73.3^{*}$ & $10.9 \pm 0.3^{*}$ \\
\hline Weekend & 88.9 & $52.6 \pm 1.4$ & $73.0^{*}$ & $28.8 \pm 0.7^{*}$ \\
\hline Rest of week & 71.0 & $11.7 \pm 0.5$ & $43.1^{*}$ & $6.7 \pm 0.3^{*}$ \\
\hline
\end{tabular}

$* P<0.01$.

the academic course, while the consumption of male students is higher $(P<0.05)$ among those who share a flat with friends (Table VI).

\section{DISCUSSION}

Like previous observations of university students [4,5] and among the general population [2] in Spain our results show that males consume alcoholic drinks more frequently and in higher quantities than females. As 


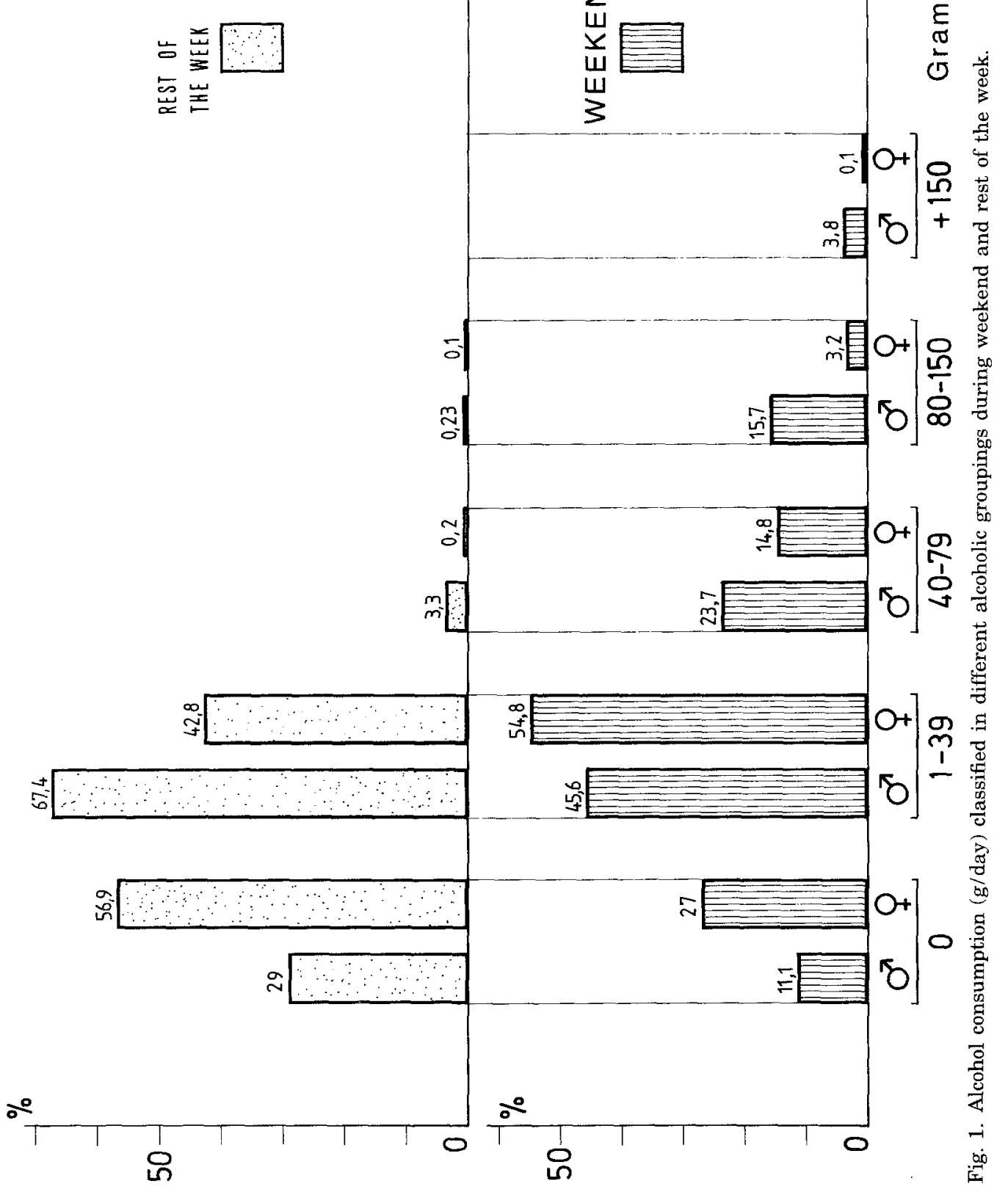


TABLE IV

KIND AND AMOUNT OF ALCOHOLIC DRINKS CONSUMED BY UNIVERSITY STUDENTS

\begin{tabular}{|c|c|c|c|c|}
\hline \multirow[t]{2}{*}{ Kind of drink } & \multicolumn{2}{|l|}{ Weekend } & \multicolumn{2}{|c|}{ Rest of week } \\
\hline & $\begin{array}{l}\% \\
\text { of students }\end{array}$ & g/day & $\begin{array}{l}\% \\
\text { of students }\end{array}$ & g/day \\
\hline Beer & 60.9 & 13.4 & $42.8^{*}$ & $4.7^{*}$ \\
\hline Wine & 40.6 & 10.4 & $30.0^{*}$ & $5.5^{*}$ \\
\hline Champagne & 13.9 & 9.0 & $1.3^{*}$ & $6.6^{*}$ \\
\hline Sherry & 5.0 & 6.6 & $1.4^{*}$ & $3.6^{*}$ \\
\hline Vermout & 28.9 & 9.0 & $4.5^{*}$ & $4.6^{*}$ \\
\hline Cognac & 10.4 & 15.0 & $2.8^{*}$ & $8.2^{*}$ \\
\hline Anisette & 6.4 & 10.8 & $1.6^{*}$ & $6.5^{*}$ \\
\hline Cognac and anisette & 3.4 & 12.5 & $0.8^{*}$ & $5.6^{*}$ \\
\hline Punch & 2.8 & 11.4 & $0.6^{*}$ & $6.4^{*}$ \\
\hline Gin & 27.1 & 23.4 & $4.1^{*}$ & $9.1^{*}$ \\
\hline Rum & 13.2 & 18.6 & $1.4^{*}$ & $9.1^{*}$ \\
\hline Vodka & 8.0 & 17.9 & $0.8^{*}$ & $6.5^{*}$ \\
\hline Whisky & 8.7 & 19.2 & $1.3^{*}$ & $9.7^{*}$ \\
\hline Cointreau & 7.6 & 11.7 & $0.7^{*}$ & $4.9^{*}$ \\
\hline Pacharan & 5.4 & 10.7 & $0.7^{*}$ & $6.1^{*}$ \\
\hline
\end{tabular}

$* P<0.01$.

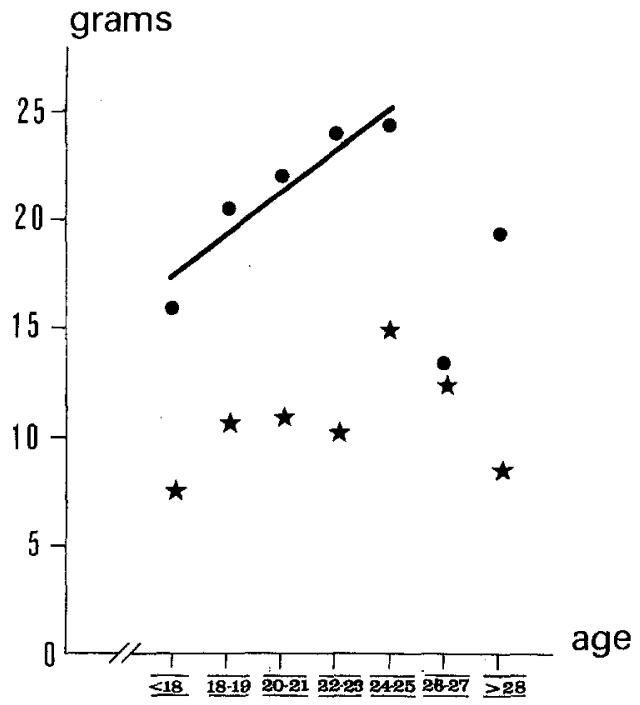

Fig. 2. Alcohol consumption (g/day) and age of university students. $\bullet$, males $(P<0.05)$; females $(P>0.05)$. 
TABLE V

CONSUMPTION OF ALCOHOL ACCORDING TO ACADEMIC YEAR

\begin{tabular}{ll}
\hline Academic year & $\mathrm{g} \pm$ S.E.M./day \\
\hline 1st & $16.1 \pm 0.6$ \\
2nd & $14.1 \pm 0.6$ \\
3rd & $17.2 \pm 0.8$ \\
4th & $16.9 \pm 1.0$ \\
5th & $17.5 \pm 1.1$ \\
6th & $16.5 \pm 2.2$
\end{tabular}

${ }^{a}$ There was no statistically significant difference between groups $(P>0.05)$.

TABLE VI

ALCOHOL CONSUMPTION ACCORDING TO PLACE OF RESIDENCE

\begin{tabular}{llc}
\hline Place of & \multicolumn{2}{l}{ Alcohol consumption (g/day) } \\
\cline { 2 - 3 } residence & Male & Female $^{\mathrm{a}}$ \\
\hline Family home & 20.6 & 11.0 \\
College room & 21.5 & 10.7 \\
Boarding house & 19.2 & 6.7 \\
In a flat with & & \\
$\quad$ & \\
$\quad$ freinds & $26.0^{*}$ & 11.4 \\
Others & 22.1 & 11.9 \\
\hline
\end{tabular}

$* P<0.05$

${ }^{a}$ There was no statistically significant difference between groups $(P>0.05)$.

other western countries alcoholic drinks were consumed especially during the weekend. Beer and wine were the favourite drinks of university students as reported elsewhere [4,5], while the general population prefers wine [2].

Consumption of acoholic drinks in Spain is to some extent a social custom [6]. Some of the present results support this idea: alcohol consumption was similar regardless of the Faculty or the academic year. Thus, medical and nursing students consume alcohol to a similar extent as the rest of the student population, which is surprising because it could be expected that knowledge of the effects of alcohol might dissuade its consumption. Female alcohol consumption is not affected by age or place of residence during the academic course. However, in male students, alcohol consumption increased with age (18-25 years), and was higher among those students who lived with flatmates.

Since 1950 (Table VII), a progressive increase in the production and consumption of alcoholic drinks has been reported in Spain [1-3]. How- 


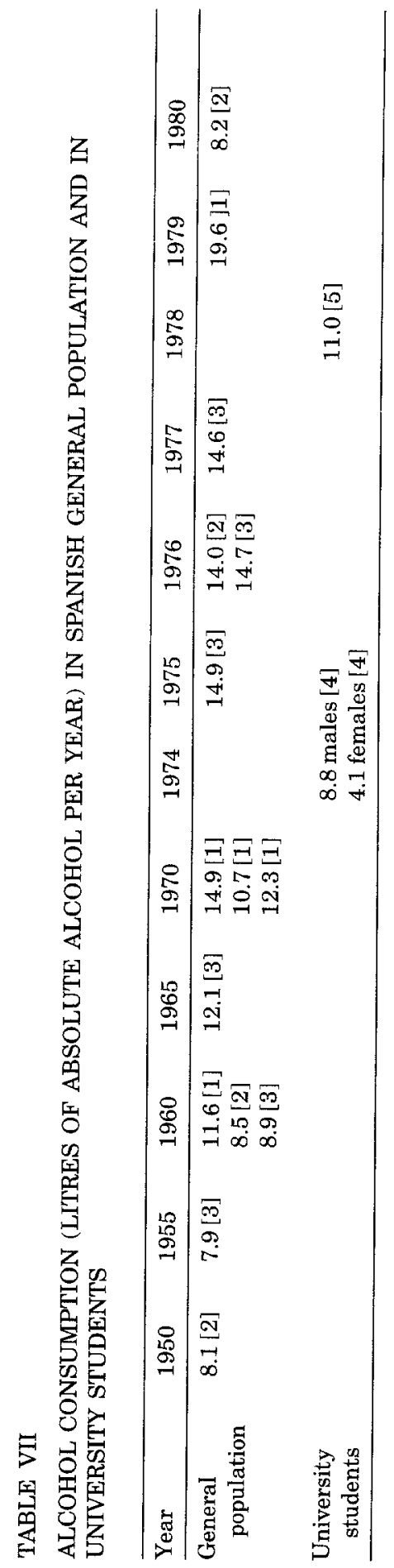


ever, the consumption figures reported (Table VII) differ markedly, in part due to the very limited data available form epidemiological studies. Nevertheless, alcohol consumption among university students (present and previous data $[4,5]$ ) was much lower than that of the general Spanish population [1-3]. The levels of alcohol consumption found (per capita consumption in litres of absolute alcohol per year: male, 9.85; female, 4.97;

average, 7.10) are in agreement with those previously reported for other Spanish university students during the academic years 1973/1974 and 1974/1975 [4], and 1977/1978 [5]. This permits the conclusion that alcohol consumption among university students in Spain has been stable during the last decade. Based on previous reports [2,3] a similar conclusion could be reached for the general population.

\section{REFERENCES}

$1 \mathrm{D}$. Walsh, Les problèmes medico-sociaux liés a la consommation d'alcohol et leur prevention, La Santé Publique en Europe 17, O.M.S., Copenhague, 1984.

2 Ministerio de Sanidad y Consumo (Ed.), Estudio de los habitos de consumo de alcohol de la poblacion adulta Espanola, Servicio de Publicaciones del Ministerio de Sanidad y Consumo, Madrid, 1984.

3 F. Freixa, M. Melgarejo and R. Rovira, Alcoholismo. Etiopatogenia: factores sociales y culturales, JANO, 656-M (1985) 17.

4 J.R. Laporte et al., Eur. J. Clin. Pharmacol., 11 (1977) 449.

5 Grupo Universitario Multicentrico, Med. Cli. (Barc.), 75 (1980) 317.

6 F. Alonso, Alcohol-Dependencia, Ediciones Piramide, Madrid, 1981. 